\title{
Terms and conditions of high-mountain lake ice-cover chemistry (Carpathians, Poland)
}

\author{
Iwona KURZYCA, ${ }^{1}$ Adam CHOIŃSKI, ${ }^{2}$ Joanna POCIASK-KARTECZKA, ${ }^{3}$ \\ Agnieszka LAWNICZAK, ${ }^{4}$ Marcin FRANKOWSKI ${ }^{1}$ \\ ${ }^{1}$ Department of Water and Soil Analysis, Adam Mickiewicz University, Poznan, Poland \\ ${ }^{2}$ Institute of Physical Geography and Environmental Planning, Adam Mickiewicz University, Poznan, Poland \\ ${ }^{3}$ Institute of Geography and Spatial Management, Jagiellonian University, Krakow, Poland \\ ${ }^{4}$ Department of Ecology and Environmental Protection, University of Life Sciences, Poznan, Poland \\ Correspondence: Iwona Kurzyca <ikurzyca@amu.edu.pl>
}

\begin{abstract}
We discuss the results of an investigation of the chemical composition of the ice cover on the high-mountain lake Morskie Oko in the Tatra Mountains, Carpathians, Poland. In the years 200713, the ice cover was characterized by an average duration of 6 months, a thickness range of $0.40-$ $1.14 \mathrm{~m}$, and a multilayered structure with water or slush inclusion. In water from the melted ice cover, chloride $(\max .69 \%)$ and sulphate $(\max .51 \%)$ anions and ammonium $(\max .66 \%)$ and calcium $(\max$. $78 \%$ ) cations predominated. Different concentrations of ions $\left(\mathrm{F}^{-}, \mathrm{Cl}^{-}, \mathrm{NO}_{3}{ }^{-}, \mathrm{SO}_{4}{ }^{2-}, \mathrm{Na}^{+}, \mathrm{K}^{+}, \mathrm{Mg}^{2+}\right.$, $\mathrm{Ca}^{2+}, \mathrm{NH}_{4}{ }^{+}$) in the upper, middle and bottom layers of ice were observed, along with long-term variability and spatial diversification within the ice layer over the lake. Snowpack lying on the ice and the water body under the ice were also investigated, and the influence on the ice cover of certain ions in elevated concentrations was observed (e.g. $\mathrm{Cl}^{-}$in the upper ice cover and the snowpack, and $\mathrm{Ca}^{2+}$ in the bottom ice cover and water body).
\end{abstract}

KEYWORDS: ice chemistry, lake ice

\section{INTRODUCTION}

In recent years, interest in high-mountain seasonally icecovered lakes has increased, mainly due to the impact of global warming on ice-cover phenology (George, 2010; Bengtsson, 2011; Benson and others, 2012). In addition, Lepparanta (2015) has recently been the first to describe in detail the ice phenomenon on lakes. However, the chemical characteristics of ice cover on high-mountain lakes have been little investigated, despite numerous admixtures (e.g. salts, ions, gas bubbles or particulate matter) which can be built up in the ice structure (Taguchi and others, 2001; Lepparanta and others, 2003; Kekonen and others, 2004; Vrbka and Jungwirth, 2005; Huthwelker and others, 2006; Luo and others, 2010; Shafique and others, 2011).

External factors, such as the physical and chemical properties of water, related to its structural polymorphism and the transitional phases at the stage of ice-cover formation, as well as conditions on the borderline between water body and atmosphere, determine the crystallographic structure of the primary ice layer (formation, and growth of crystals, marked by different morphological features (e.g. congelation or frazil ice)) (Bartels-Rausch and others, 2012a; Kirillin and others, 2012). Regularly or randomly oriented axes of crystals determine the further growth of an ice cover with miscellaneous structure, resulting in different affinity with regard to building-in foreign substances dissolved in the solid and gas (Ikeda-Fukazawa and Kawamura, 2006; Bartels-Rausch and others, 2012a; Kirillin and others, 2012). As ice-cover growth occurs both on the surface and from the bottom, different factors also affect its chemical composition (Bengtsson, 2011).

In favorable conditions, surface growth of the ice is related to atmospheric precipitation. The infiltration of pollutants then comes about as a result of various mechanisms, especially in the seasonal melting/freezing periods (Kang, 2005; Ashton, 2011; Bengtsson, 2011). In this case, ice quality is strongly affected by the chemical composition of atmospheric precipitation and dry atmospheric deposition from the non-precipitation periods (Lilbæk and Pomeroy, 2008), as well as air quality (Bartels-Rausch and others, 2014). The amount of bound pollutants per ice capacity unit depends on the speed and nature of ice-cover growth, as it is of great importance whether the growth is stepwise or systematic and gradual (Shafique and others, 2011; BartelsRausch and others, 2012b).

The growth of an ice cover on the borderline with the water body is mainly determined by the temperature (heat balance) and properties of water in a meta-stable cold state (unfortunately, this phenomenon has not been thoroughly investigated; Nevzorov, 2006). Alien substances may be adsorbed on the ice surface, and even penetrate deeper ice layers through diffusion (Park and others, 2010). Protogenic (crystal inclusions), syngeneic (simultaneous growth) or epigenetic (filling the slots) inclusions can occur (Taguchi and others, 2001).

The ice structure may also comprise water inclusions: layers of non-frozen water between ice layers (Bengtsson, 2012). The water is characterized by especially high pollution, as during the process of freezing and forming the ice crystals the kryochemical effect occurs, resulting in the concentration of chemical compounds. The concentration of alien substances pushed outside the crystal structure of ice increases due to the decreasing amount of water (the solvent), while the amount of dissolved substances remains the same (Lorain and others, 2001; Carignano and others, 2007). In winter the accumulation 


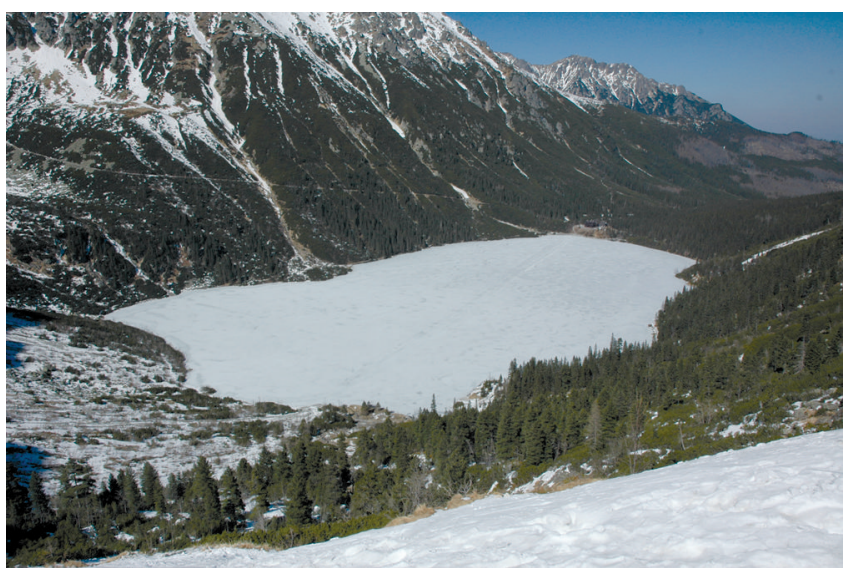

Fig. 1. Morskie Oko lake.

of pollutants takes place both on the surface of the icecovered lake and the area of the lake watershed; the water body of the lake has thus been isolated (Varilova and others, 2011). Moreover, access of light and oxygen to the water body is decreased and the thermal condition changes, unfavorably affecting chemical and biological processes in the water body (Catalan and others, 1992; Lilbæk and Pomeroy, 2008). Later, during the short period of ice melting, the pollutants are released into the water body, which may cause significant unbalancing of the lake ecosystem (Adams and Roulet, 1984; Girardet and Toubin, 2001; Ikeda-Fukazawa and Kawamura, 2006).

The aim of the research is to describe the chemical composition of ice cover on the seasonally freezing high mountain lake. We attempt to explain the influence of weather conditions, chemical composition of lake water and air quality on the chemistry of the ice cover.

\section{STUDY AREA}

Morskie Oko lake $\left(49^{\circ} 11^{\prime} 49^{\prime \prime} \mathrm{N}, 20^{\circ} 04^{\prime} 12^{\prime \prime} \mathrm{E}\right)$ lies on the northern side of the High Tatra Mountains (western Carpathians, Poland) in the Rybi Potok valley, in the Tatra National Park (Fig. 1).

This reservoir (area 34.9 ha; maximum depth $58.1 \mathrm{~m}$ ) is situated $1395 \mathrm{~m}$ a.s.I., in the granite range, and occupies the lowest parts of the postglacial hollow closed with a moraine step. The borders of the cirque and lower parts of the slopes are covered with stone rubble and glacial till, and dwarf pine separated by naked scree reaches its rim. Mountain peaks surrounding the lake rise $\sim 1000 \mathrm{~m}$ above its surface, causing extreme reduction of solar radiation to the lake surface (80-90\% in January). Morskie Oko lies within a cool climate zone (corresponding to an upper sub-alpine forest vegetation zone). The ice phenomena on Morskie Oko lake usually last for 6 months (November-May) each year. However, long-term trends (1971-2010) indicate that the duration of ice cover on the lake has been decreasing at a rate of 1 day $\mathrm{a}^{-1}$, corresponding to the increase in temperature from November to May $\left(1.4^{\circ} \mathrm{C}(100 \mathrm{a})^{-1}\right)$ (PociaskKarteczka and Choiński, 2012). This global problem increasingly affects aquatic ecosystems.

This reservoir is mainly supplied by precipitation, directly and indirectly in the form of surface runoff and rock mantle runoff. A large contribution to the lake water supply comes from molten snow and ice. The annual precipitation usually

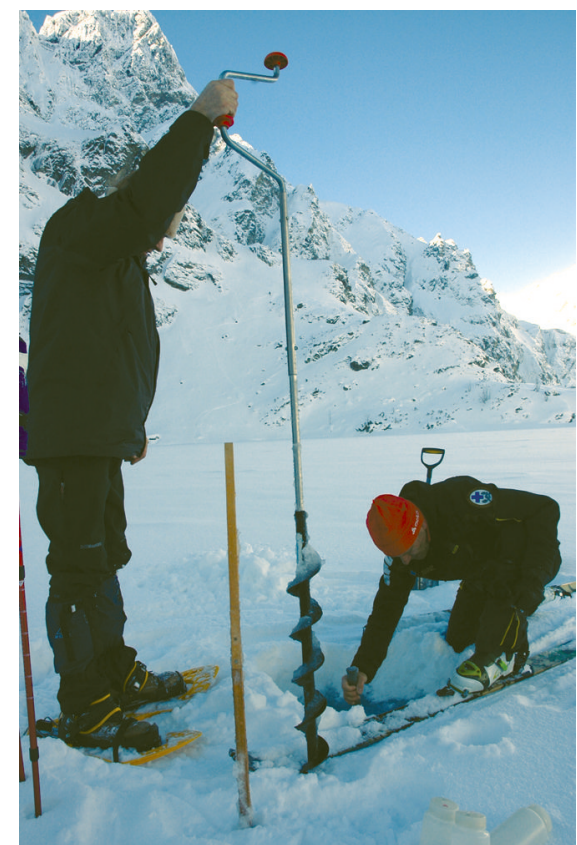

Fig. 2. Drilling in the Morskie Oko ice cover.

exceeds $1600 \mathrm{~mm}$, and one-third of precipitation falls in the winter months. The contribution of solid precipitation (e.g. snow, hail) to the mean annual precipitations reaches $24 \%$ (Pajak, 2011, 2012). The oligotrophic lake water is characterized by $15 \mathrm{~m}$ Secchi transparency (Choiński and others, 2010) with a sparse number of flora and fauna species. The rocky bottom covers a thin layer of sediments, mainly mineral.

\section{MATERIALS AND METHODS}

The study was conducted during winter, at nearly 1400 ma.s.I., in particularly difficult conditions: abundant snow cover, low temperature, thick ice cover, avalanches and, as a result of their descent, possible cracking of the ice cover.

Ice samples were collected during the first quarter of the years 2007-13 in the central part of the lake. From 2007 to 2009, samples were also taken from the second point located $\sim 100 \mathrm{~m}$ north of the center. Due to the Tatra National Park regulations and the threat of avalanche, the drillings were performed with a hand drill (Fig. 2).

Samples were collected from the upper part of the ice (up to $10 \mathrm{~cm}$ from its surface), the middle part (determined according to ice thickness) and the lower (bottom) part. The water from under the ice was also collected by pumping through a $1.5 \mathrm{~cm}$ diameter vinyl pipe. A sample of snow lying on the ice was also taken.

After transportation to the laboratory, the samples were melted at room temperature and analyzed. Measurements of $\mathrm{pH}$ and electrical conductivity were conducted using a Thermo Orion 4-Star (USA) device. The ion composition $\left(\mathrm{F}^{-}\right.$, $\left.\mathrm{Cl}^{-}, \mathrm{NO}_{3}{ }^{-}, \mathrm{PO}_{4}{ }^{3-}, \mathrm{SO}_{4}{ }^{2-}, \mathrm{Na}^{+}, \mathrm{K}^{+}, \mathrm{Mg}^{2+}, \mathrm{Ca}^{2+}, \mathrm{NH}_{4}{ }^{+}\right)$was determined after filtrating a sample $(0.45 \mu \mathrm{m})$ using the ion chromatography method with conductometric detection (Dionex 120, USA). In order to validate the reliability of the performed analyses, the reference material marked by low ionic strength was analyzed, with satisfying results, according to Walna and others (2004). 
Table 1. Results of investigation of samples (snow and ice covers, water) from Morskie Oko lake in years $2007-13\left(\mathrm{mg} \mathrm{L}^{-1}\right)($ relative standard deviation $<5 \%$ )

\begin{tabular}{|c|c|c|c|c|c|c|c|c|c|c|}
\hline & & $\mathrm{F}^{-}$ & $\mathrm{Cl}^{-}$ & $\mathrm{NO}_{3}^{-}$ & $\mathrm{SO}_{4}{ }^{2-}$ & $\mathrm{Na}^{+}$ & $\mathrm{NH}_{4}{ }^{+}$ & $\mathrm{K}^{+}$ & $\mathrm{Mg}^{2+}$ & $\mathrm{Ca}^{2+}$ \\
\hline \multirow{3}{*}{$\begin{array}{l}\text { Snow } \\
n=7\end{array}$} & $\min$ & 0.01 & 0.21 & 0.33 & 0.21 & 0.11 & 0.31 & 0.07 & 0.01 & 0.17 \\
\hline & $\max$ & 0.11 & 1.79 & 3.47 & 2.85 & 0.62 & 1.25 & 0.32 & 0.20 & 2.60 \\
\hline & median & 0.01 & 1.28 & 0.47 & 0.57 & 0.35 & 0.40 & 0.13 & 0.02 & 0.19 \\
\hline \multirow{2}{*}{$\begin{array}{l}\text { Top ice } \\
n=9\end{array}$} & $\min$ & 0.01 & 0.42 & 0.15 & 0.14 & 0.17 & 0.05 & 0.06 & 0.01 & 0.06 \\
\hline & median & 0.01 & 1.23 & 0.71 & 1.10 & 0.30 & 0.41 & 0.17 & 0.03 & 0.47 \\
\hline \multirow{3}{*}{$\begin{array}{l}\text { Middle ice } \\
n=9\end{array}$} & $\min$ & 0.01 & 0.29 & 0.35 & 0.21 & 0.09 & 0.05 & 0.04 & 0.01 & 0.28 \\
\hline & $\max$ & 0.05 & 1.85 & 5.99 & 5.21 & 1.29 & 1.54 & 0.48 & 0.31 & 6.42 \\
\hline & median & 0.03 & 0.49 & 1.01 & 1.19 & 0.20 & 0.58 & 0.12 & 0.03 & 0.70 \\
\hline \multirow{2}{*}{$\begin{array}{l}\text { Bottom ice } \\
n=10\end{array}$} & $\min$ & 0.01 & 0.26 & 0.41 & 0.27 & 0.10 & 0.04 & 0.04 & 0.01 & 0.14 \\
\hline & $\max$ & 0.03 & 1.92 & 6.98 & 6.61 & 1.43 & 1.17 & 0.81 & 0.37 & 6.93 \\
\hline \multirow{3}{*}{$\begin{array}{l}\text { Water } \\
\text { under ice } \\
n=11\end{array}$} & $\min$ & 0.01 & 0.33 & 1.59 & 1.97 & 0.22 & 0.09 & 0.08 & 0.05 & 1.36 \\
\hline & $\max$ & 0.02 & 0.92 & 2.83 & 3.92 & 0.67 & 0.43 & 0.33 & 0.15 & 4.41 \\
\hline & median & 0.02 & 0.55 & 2.00 & 2.96 & 0.39 & 0.16 & 0.12 & 0.08 & 2.35 \\
\hline
\end{tabular}

\section{RESULTS AND DISCUSSION}

\section{Structure of the ice cover}

In the years 2007-13, the ice phenomena usually occurred between 17 November and 15 May on Morskie Oko lake, while the ice cover occurred between 26 November and 3 May. Ice-cover thickness varied from 0.40 to $1.14 \mathrm{~m}$, with a maximum yearly mean of $0.67 \mathrm{~m}$. The ice structure was often multilayered, consisting of two layers of ice between which was a layer of water and/or slush (water with snow crystals). The bottom layer of ice was usually thicker than the upper layer.

The formation of such a cover is connected with severalday-long warmer periods (usually in the second phase of winter) when the ice surface or the snow covering it may partly melt. Rainfall may also occur. Water gathering on the surface begins to refreeze, with the temperatures below zero, but depending on the intensity of snowfall it may be to a different extent 'saturated' (pervaded), which is why it takes the form of slush (snow mud). In its final phase, winter is usually too mild to freeze the whole layer of water, so multilayered ice is formed, i.e. 'inter-water' ice in various stages of water crystallization (Choiński and others, 2010; Pociask-Karteczka and Choiński, 2012). Other studies indicate weather conditions as the main cause of the multilayered structure of the ice cover (e.g. Catalan and others, 1992; Duguay and others, 2003).

\section{Physical and chemical properties of ice, snow and water in lake Morskie Oko}

The salt content in the structure of ice measured as electrical conductivity of water from the melted ice cover (upper, middle and bottom parts) was quite diversified in the years 2007-13, ranging from 7 to $38 \mu \mathrm{Scm}^{-1}$, and mostly did not exceed $25 \mu \mathrm{S} \mathrm{cm}^{-1}$, whereas the electrical conductivity of lake water ranged from 18 to $29 \mu \mathrm{Scm}^{-1}$. The highest values of electrical conductivity in relation to the bottom, middle and upper parts of the ice cover were observed in 2012 and were 36,27 and $24 \mu \mathrm{S} \mathrm{cm}^{-1}$ respectively. The lowest values for all three layers were observed in 2010, falling below
$16 \mu \mathrm{Scm}^{-1}$. The analysis of results in relation to the profiles showed higher pollution in the bottom layer of ice than in the upper part. Conductivity values measured in the Morskie Oko lake ice cover are similar to other high-mountain lakes (Lepparanta and others, 2003), and indicate a contribution of impurities. This can be attributed to processes associated with ice-cover formation (Taguchi and others, 2001; Luo and others, 2010), as well as during the cover persistence (Bordonsky and Krylov, 2000; Kang, 2005).

Analysis of the $\mathrm{pH}$ of water from the melted ice cover showed values in the range 6.2-6.9, and no relationship was observed between the $\mathrm{pH}$ and the location of the layer from which the ice sample was collected. Considering the fact that $\mathrm{pH}$ is the resultant of the presence of acidifying and alkalizing ions, as a well as the content of dissolved $\mathrm{CO}_{2}$, one may assume that the influence of external factors does not contribute significantly to changes in the $\mathrm{pH}$ of the ice cover.

In water from the melted ice cover, chloride (max 69\%) and sulphate $(\max 51 \%$ ) ions dominate among the anions, and ammonium ( $\max 66 \%$ ) and calcium (max $78 \%$ ) ions among the cations. The lowest contributors to the ionic balance are fluoride and magnesium ions (Table 1). In the upper layer of ice, the highest concentrations were mainly those of chlorides (in six cases out of nine) and sulphates (three cases out of nine), while nitrate ions reached lower concentrations (Fig. 3). In the middle and bottom layers of the ice cover, the highest concentrations were observed mainly for sulphates, in six out of nine and six out of ten cases respectively (Figs 4 and 5). In samples from these layers, increased concentrations were also measured for nitrate anions (maximum 5.99 and $6.98 \mathrm{mg} \mathrm{L}^{-1}$ respectively), which was not observed in the upper part of the ice cover (maximum $2.18 \mathrm{mg} \mathrm{L}^{-1}$ ). The highest concentrations of cations occurred in the case of calcium ions in the bottom layer of the ice (median $1.02 \mathrm{mg} \mathrm{L}^{-1}$ ), and lowest concentrations in the upper part (median $0.47 \mathrm{mg} \mathrm{L}^{-1}$ ). At the same time, measured values occurred in the broad range between $0.06 \mathrm{mg} \mathrm{L}^{-1}$ (2007) and $6.93 \mathrm{mg} \mathrm{L}^{-1}$ (2012). The maximum concentration of ammonium ions $\left(1.81 \mathrm{mg} \mathrm{L}^{-1}\right)$ was observed in the upper layer. Nevertheless, in this layer, 


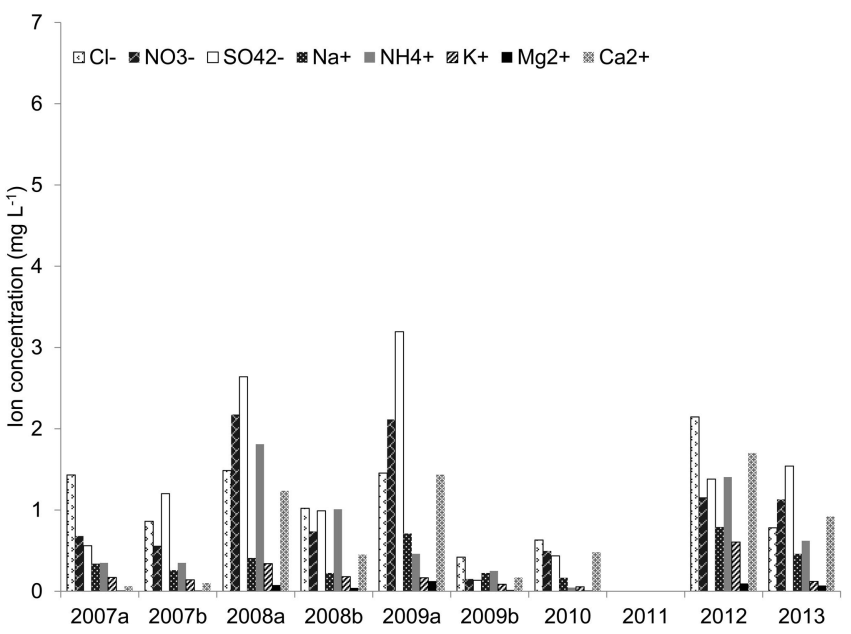

Fig. 3. Chemical characteristics of Morskie Oko lake ice cover (top ice) in the period 2007-13 (a and b represent parallel drillings, spaced $\sim 100 \mathrm{~m}$ apart).

average concentration values were the lowest in the whole profile (median $0.41 \mathrm{mg} \mathrm{L}^{-1}$ ). The contribution of ammonium ions was the highest in the bottom layer (median $0.72 \mathrm{mg} \mathrm{L}^{-1}$ ). Sodium ions occurred mostly on a similar level of concentration regardless of the layer from which the ice sample was collected, which is confirmed by similar median values ranging between 0.20 and $0.30 \mathrm{mg} \mathrm{L}^{-1}$. A similar distribution of pollutants in a profile was also observed in the case of potassium and magnesium ions, but their concentrations were lower. The medians ranged between 0.12 and $0.19 \mathrm{mg} \mathrm{L}^{-1}$ and between 0.03 and $0.05 \mathrm{mg} \mathrm{L}^{-1}$ respectively (Table 1 ; Figs $3-5$ ). It should be noted that the penetration of ions in the structure of ice strictly depends on the borderline conditions (Bryk and Haymet, 2004). During 7 years of research, different atmospheric conditions have been observed, marked by varying ice structure, so conclusions should be formulated with particular care. Nevertheless, a few studies worldwide indicate similar results (Catalan, 1989; Bordonsky and Krylov, 2000; Lepparanta and others, 2003).

It is noteworthy that significant differences between samples from the same layers were observed within the ice cover, despite the analogous depth of sample collection (Figs 3-5). In the years 2007-09, when two drillings

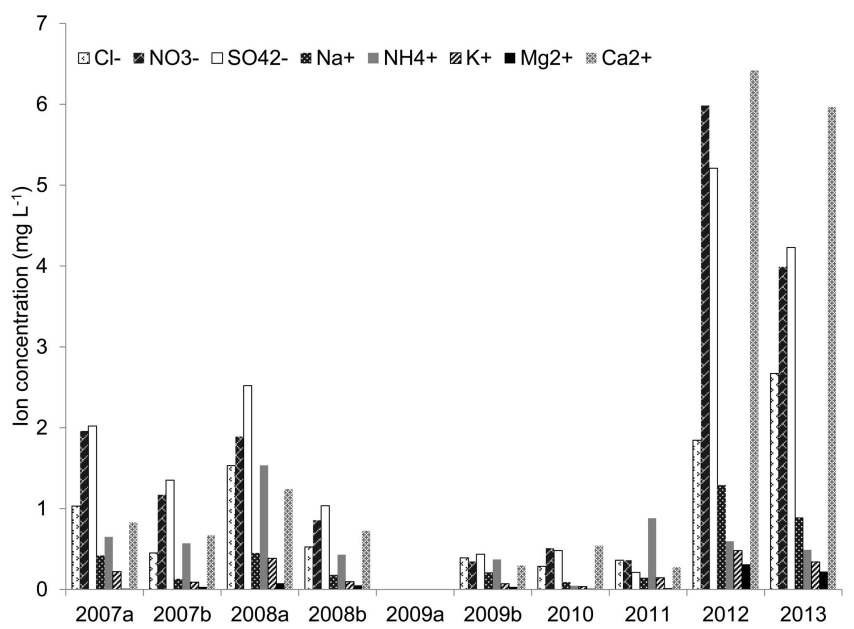

Fig. 4. Same as Figure 3 but for middle ice.

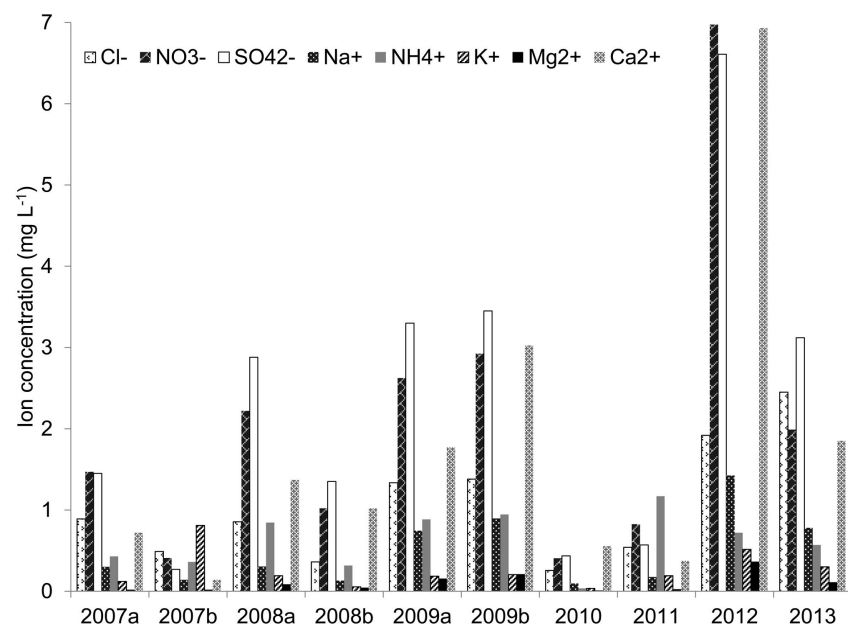

Fig. 5. Same as Figure 3 but for bottom ice.

(Figs 3-5; a and b) were made, differences between the sampling points were observed in all layers (top, middle, bottom), with the most significant differences occurring in the surface part (2009), where the difference in mineralization represented by electrical conductivity was $>100 \%$ (7 and $16 \mu \mathrm{S} \mathrm{cm}^{-1}$ ). Moreover, depending on the ion type, differences within particular layers were distributed irregularly. In 2007, at one point (central part of the lake), higher concentrations of chloride ions but lower concentrations of sulphate were observed, while the other ions occurred at similar concentration levels. The variable thickness of the ice cover over the lake, as well as different physicochemical properties of ice samples collected at the same depth, confirm the heterogeneous chemical composition caused by external factors and the kryochemical effect (Bartels-Rausch and others, 2012a).

In the years 2007-13, the ice on lake Morskie Oko was usually covered by a snow layer several $\mathrm{cm}$ to several tens of $\mathrm{cm}$ thick. The exception was 2010, when there was no snow cover in the sample collection period (March). Earlier that year, precipitation did not exceed $100 \mathrm{~mm} \mathrm{month}^{-1}$ (Pajak, 2011). Consequently, wind, snow sublimation and melting caused the lack of snow cover. Analysis of the chemical composition of snow lying on the surface of the ice cover over lake Morskie Oko showed similar or lower concentrations of particular ions in comparison with the results obtained for the upper part of the ice cover (Table 1). Chlorides dominated among the anions, while ammonium and sodium ions prevailed among the cations. However, it should be emphasized that the analyzed samples were the old (seasonal) snow, which underwent numerous changes with time, such as metamorphism and elution of admixtures from the crystal structure (Catalan, 1989; Catalan and others, 1992; Lilbæk and Pomeroy, 2008; Bartels-Rausch and others, 2012b). The monitoring of atmospheric pollutant loads over the Tatra Mountains allows for the observation that wintertime precipitation brings $7.4 \mathrm{~kg} \mathrm{SO}_{4}{ }^{2-} \mathrm{ha}^{-1}, 3.7 \mathrm{~kg}$ $\mathrm{Cl}^{-} \mathrm{ha}^{-1}, 3.0 \mathrm{~kg} \mathrm{NO}_{3}{ }^{-} \mathrm{ha}^{-1}, 2.1 \mathrm{~kg} \mathrm{Ca}^{2+} \mathrm{ha}^{-1}, 1.4 \mathrm{~kg} \mathrm{Na}^{+} \mathrm{ha}^{-1}$ and $2.3 \mathrm{~kg} \mathrm{~K}^{+} \mathrm{ha}^{-1}$ (e.g. November 2010-March 2011; Pajak, 2011, 2012). Atmospheric deposition (including pollutants), as well as other factors, i.e. ionic permeability of ice lattice in relation to the reduction of temperature, ice crystal size and incorporation of ions in the ice lattice, contributes to the chemical composition of ice cover. It can be seen that $\mathrm{Na}^{+}: \mathrm{Cl}^{-}$ratios by weight in snow (0.28) and ice 
(0.24-0.40) are closer to the sea water (0.55), indicating that they are primarily atmospheric in origin, derived from sea salt via precipitation. Molar ratios of $\mathrm{NH}_{4}{ }^{+}: \mathrm{SO}_{4}{ }^{2-}$ in snow and ice (4:1 to $2: 1$ respectively) are closer to the ideal ratio $2: 1$, indicating the formation of $\left(\mathrm{NH}_{4}\right)_{2} \mathrm{SO}_{4}$ by postdeposition photochemical reactions in the atmosphere. Also the $\mathrm{Ca}^{2+}: \mathrm{Cl}^{-}$ratio by weight is much higher (4.50) than that of snow (0.15) and ice (0.38-1.18). The ion $\mathrm{Ca}^{2+}$ could be mainly derived from the weathering of rocks in the drainage basins.

Electrical conductivity of water in the lake ranged from 18 to $29 \mu \mathrm{S} \mathrm{cm}^{-1}\left(20-25 \mu \mathrm{S} \mathrm{cm}^{-1}\right.$ predominantly), with the highest contributions from sulphate and nitrogen ions and calcium cations. Atmospheric deposition is considered to be the source of these ions in the Tatra reservoirs, while the alkaline ions, including the calcium ion, mainly originate from the reaction of weathering and processes of ion exchange in catchment soil (Rzychon, 2009).

Comparison of the oligotrophic water of lake Morskie Oko (predominantly $20-25 \mu \mathrm{S} \mathrm{cm}^{-1}$ ) with the ice cover reveals lower mineralization of ice (most often in the range $7-25 \mu \mathrm{Scm}^{-1}$ ). The average value of total ions, $118 \mu \mathrm{Eq} \mathrm{L}^{-1}$, is lower than that of water $\left(163 \mu \mathrm{EqL}^{-1}\right)$. Also, the order of abundance of ions in lake water under the ice $\left(\mathrm{Ca}^{2+}>\right.$ $\left.\mathrm{Na}^{+}>\mathrm{Mg}^{2+}>\mathrm{K}^{+}>\mathrm{NH}_{4}{ }^{+} ; \mathrm{NO}_{3}{ }^{-}>\mathrm{SO}_{4}{ }^{2-}>\mathrm{Cl}^{-}>\mathrm{F}^{-}\right)$is different from that of ice cover (top: $\mathrm{NH}_{4}^{+}>\mathrm{Na}^{+}>\mathrm{Ca}^{2+}>\mathrm{K}^{+}>$ $\mathrm{Mg}^{2+} ; \mathrm{Cl}^{-}>\mathrm{NO}_{3}{ }^{-}=\mathrm{SO}_{4}{ }^{2-}>\mathrm{F}^{-}$, middle: $\mathrm{NH}_{4}{ }^{+}>\mathrm{Ca}^{2+}>\mathrm{K}^{+}$ $>\mathrm{Mg}^{2+}>\mathrm{Na}^{+} ; \mathrm{NO}_{3}{ }^{-}>\mathrm{Cl}^{-}>\mathrm{SO}_{4}{ }^{2-}>\mathrm{F}^{-}$, bottom: $\mathrm{NH}_{4}{ }^{+}$ $>\mathrm{Ca}^{2+}>\mathrm{Na}^{+}>\mathrm{K}^{+}>\mathrm{Mg}^{2+} ; \mathrm{Cl}^{-}>\mathrm{NO}_{3}{ }^{-}>\mathrm{SO}_{4}{ }^{2-}>\mathrm{F}^{-}$). Lower medians of concentrations for nitrate, sulphate, magnesium and calcium ions are observed in the ice cover than in the lake water. However, it is interesting that, in the case of chloride, potassium and especially ammonium ions, higher average concentration values are found in the ice cover (Table 1). The catchment characteristic in terms of geochemical processes, as well as the annual, biological cycle of the reservoir, may play a significant role. Similar results were obtained by Lepparanta and others (2003) for an oligotrophic ice-covered lake in Finland, while this phenomenon was not observed in lakes with higher mineralization of water.

On the other hand, the ice cover on the sea has been studied in numerous works (e.g. by Weeks, Bartels-Rausch). It has been stated that the binding impurities from fresh and salty water into the ice may vary due to different process conditions and ice-cover structure (Vrbka and Jungwirth, 2005; Luo and others, 2010; Timco and Weeks, 2010; Lepparanta, 2015) and in ice cover on the sea some salinity variation in the ice cover profile is usually observed. The differentiation in salinity in ice is connected with the migration of salt downward through the ice (Timco and Weeks, 2010). A similar effect was observed in Morskie Oko lake ice, although ionic concentration (salt content) in oligotrophic water and sea water varies considerably. It is very likely that the salinity of lake water affects the cycle of freezing and defreezing observed in the high-altitude lake (Lepparanta, 2015).

Based on our study, it can be stated that the analysis of the chemical composition of the ice cover on lake Morskie Oko is very significant, especially since the environmental effects, in the form of increased ion concentrations (Rzychon, 2009), decreased water pH (Kopacek and others, 2006) and release of toxic compounds to the water depth (Borowiak and others, 2006), have already been observed in some mountain lakes (Kurzyca and others, 2009).

\section{SUMMARY}

Our study conducted in the years 2007-13 showed that the Morskie Oko lake ice cover has a multilayered structure (with a layer of non-frozen water). Diversified concentration of particular ions in the upper, middle and bottom layers of the ice was observed, along with the long-term variability and spatial diversification within the ice layer over the lake. In the upper part, chloride and nitrate ions were most frequent, in the middle part sulphate and nitrate ions prevailed, while in the bottom layer nitrate, sulphate and calcium ions dominated. It is interesting that concentrations of chloride and ammonium ions are higher in the bottom layer of ice than in the lake water. Some cases of increased concentration of ions were observed in the chemical composition of ice and snow, which may be related to the deposition of pollutants from the atmosphere.

Evaluation of the 7 year study and available literature data indicates that research on the mechanisms affecting pollutants binding in the structure of the ice cover (which are affected by so many unpredictable external factors) is possible only in situ, which in the wintertime at high altitudes is a challenge for researchers.

\section{REFERENCES}

Ashton GD (2011) River and lake ice thickening, thinning, and snow ice formation. Cold Reg. Sci. Technol. 68, 3-19 (doi: 10.1016/j.coldregions.2011.05.004)

Bartels-Rausch T and 16 others (2012a) Ice structures, patterns, and processes: a view across the ice-fields. Rev. Mod. Phys., 84, 885-944 (doi: 10.1103/RevModPhys.84.885)

Bartels-Rausch T and 25 others (2012b) Relationship between snow microstructure and physical and chemical processes. Atmos. Chem. Phys., 12, 30 409-30 541 (doi: 10.5194/acpd-12-304092012)

Bartels-Rausch T and 25 others (2014) A review of air-ice chemical and physical interactions (AICl): liquids, quasi-liquids, and solids in snow. Atmos. Chem. Phys., 14, 1587-1633 (doi: 10.5194/acp-14-1587-2014)

Bengtsson L (2011) Ice-covered lakes: environment and climaterequired research. Hydrol. Process., 25, 2767-2769 (doi: 10.1002/hyp.8098)

Bengtsson L (2012) Ice covered lakes. In Bengtsson L, Herschy RW and Fairbridge RW eds. Encyclopedia of lakes and reservoirs. Springer, Dordrecht, 357-360 (doi: 10.1007/978-1-4020-44106_210)

Benson BJ and 9 others (2012) Extreme events, trends, and variability in Northern Hemisphere lake-ice phenology (18552005). Climatic Change 112, 299-323 (doi 10.1007/s10584011-0212-8)

Bordonsky GS and Krylov SD (2000) Sail inclusion migration in ice cover of Trans-Baikal lakes. An Izvestia, Geographic Series 4, 98-102 [in Russian]

Borowiak D, Polkowska Ż and Przyjazny A (2006) The hydrochemistry of high-altitude lakes in selected mountain ranges of Central and Southern Europe. Limnol. Rev., 6, 21-30

Bryk T and Haymet ADJ (2004) Charge separation at the ice/water interface: a molecular dynamics simulation study of solute ions at the ice basal plane. J. Mol. Liquids, 112,47-50 (doi: 10.1016/ j.molliq.2003.11.008)

Carignano MA, Shepson PB and Szleifer I (2007) lons at the ice/ vapor interface. Chem. Phys. Lett., 436, 99-103 (doi: 10.1016/ j.cplett.2007.01.016)

Catalan J (1989) The winter cover of a high-mountain Mediterranean lake (Estany Redo, Pyrenees). Water Resour. Res. 25, 519-527 (doi: 10.1029/WR025i003p00519) 
Catalan J, Ballesteros E, Camarero L, Felip M and Gacia E (1992) Limnology of the Pyrenean lakes. Limnetica, 8, 27-38

Choiński A, Kolendowicz L, Pociask-Karteczka J and Sobkowiak L (2010) Changes in lake ice cover on the Morskie Oko Lake, Poland (1971-2007). Adv. Climate Change Res., 1, 71-75 (doi: 10.3724/SP.J.1248.2010.00071)

Duguay CR, Flato GM, Jeffries MO, Ménard P, Morris K and Rouse WR (2003) Ice-cover variability on shallow lakes at high latitudes: model simulations and observations. Hydrol. Process., 17, 3465-3483 (doi: 10.1002/hyp.1394)

George G (2010) The impact of climate change on European lakes. (Aquatic Ecology Series) Springer, Dordrecht, Heidelberg, London and New York (doi: 10.1007/978-90-481-2945-4)

Girardet C and Toubin C (2001) Molecular atmospheric pollutant adsorption on ice: a theoretical survey. Surf. Sci. Rep., 44, 159-238 (doi: 10.1002/chin.200217295)

Huthwelker T, Ammann M and Peter T (2006) The uptake of acidic gases on ice. Chem. Rev., 106, 1375-1444 (doi: 10.1021/ cr020506v)

Ikeda-Fukazawa T and Kawamura K (2006) Effects of ions on dynamics of ice surface. Chem. Phys. Lett., 417, 561-565 (doi: 10.1016/j.cplett.2005.10.077)

Kang H (2005) Chemistry of ice surfaces: elementary reaction steps on ice studied by reactive ion scattering. Acc. Chem. Res., 38, 893-900 (doi: 10.1021/ar0501471)

Kekonen T, Peramaki P and Moore JC (2004) Comparison of analytical results for chloride, sulfate and nitrate obtained from adjacent ice core samples by two ion chromatographic methods. J. Environ. Monit., 6, 147-152 (doi: 10.1039/b306621e)

Kirillin G and 11 others (2012) Physics of seasonally ice-covered lakes: a review. Aquat. Sci., 74, 659-682 (doi: 10.1007/s00027012-0279-y)

Kopacek J, Stuchlík E and Hardekopf D (2006) Chemical composition of the Tatra Mountain lakes: recovery from acidification. Biol. Brat., 61, S21-S33 (doi: 10.2478/s11756-006-0117-6)

Kurzyca I, Choiński A, Kaniecki A and Siepak J (2009) Water ecosystems affected by human impact within the protected area of the Tatra National Park (Poland). Oceanol. Hydrobiol. Stud., 37, 77-86 (doi: 10.2478/v10009-009-0034-4)

Lepparanta M (2015) Freezing of lakes and the evolution of their ice cover. Springer-Verlag, Berlin and Heidelberg (doi: 10.1007/ 978-3-642-29081-7)

Lepparanta M, Tikkanen M and Virkanen J (2003) Observations of ice impurities in some Finnish lakes. Proc. Eston. Acad. Sci. Chem., 52, 59-75

Lilbæk G and Pomeroy JW (2008) Ion enrichment of snowmelt runoff water caused by basal ice formation. Hydrol. Process., 22, 2758-2766 (doi: 10.1002/hyp.7028)
Lorain O, Thiebaud P, Badorc E and Aurelle Y (2001) Potential of freezing in wastewater treatment: soluble pollutant applications. Water Res., 35, 541-547 (doi: 10.1016/S0043-1354(00)00287-6)

Luo C, Chen W and Han W (2010) Experimental study on factors affecting the quality of ice crystal during the freezing concentration for the brackish water. Desalination, 260, 231-238 (doi: 10.1016/j.desal.2010.04.018)

Nevzorov AN (2006) Internal mechanism of metastable liquid water crystallization and its effects on intracloud processes. Izv. Atmos. Oceanic Phys., 42, 765-772 (doi: 10.1134/ S0001433806060107)

Pajak B (2011) Report on the condition of the environment in the Małopolska region in 2010. Inspectorate of Environmental Protection, Krakow [in Polish]

Pajak B (2012) Report on the condition of the environment in the Małopolska region in 2011. Inspectorate of Environmental Protection, Krakow [in Polish]

Park SC, Moon ES and Kang H (2010) Some fundamental properties and reactions of ice surfaces at low temperatures. Phys. Chem. Chem. Phys., 12, 12 000-12 011 (doi: 10.1039/C003592K)

Pociask-Karteczka J and Choiński A (2012) Recent trends in ice cover duration for Lake Morskie Oko (Tatra Mountains, EastCentral Europe). Hydrol. Res., 43, 500-506 (doi: 10.2166/ nh.2011.019)

Rzychon D (2009) The reaction of catchment area of high-altitude lakes from atmospheric, acid deposition changes to the example of selected lakes in the Tatra Mountains. Economics and the Environment, Bialystok [in Polish]

Shafique $U$ and 11 others (2011) Chemistry of ice: migration of ions and gases by directional freezing of water. Arab. J. Chem. (doi: 10.1016/j.arabjc.2011.02.019)

Taguchi Y, Guo J and Yamaguchi T (2001) Inclusion phenomena of phosphate and ammonium ions in spherically shaped ice. Powder Technol., 121, 68-73 (doi: 10.1016/S0032-5910(01) 00376-X)

Timco GW and Weeks WF (2010) A review of the engineering properties of sea ice. Cold Reg. Sci. Technol., 60, 107-129 (doi: 10.1016/j.coldregions.2009.10.003)

Varilova Z, Prikryl R and Cilek V (2011) Pravcice Rock Arch (Bohemian Switzerland National Park, Czech Republic) deterioration due to natural and anthropogenic weathering. Environ. Earth Sci., 63, 1861-1878 (doi: 10.1007/s12665-010-0881-z)

Vrbka L and Jungwirth P (2005) Brine rejection from freezing salt solutions: a molecular dynamics study. Phys. Rev. Lett., 95, 148501-1-148501-4 (doi: 10.1103/PhysRevLett.95.148501)

Walna B, Kurzyca I and Siepak J (2004) Local effects of pollution on chemical composition of precipitation in areas differing in human impact. Pol. J. Environ. Stud. 13, 36-42 